\title{
Changes in plant community diversity and composition across an edge between Araucaria forest and pasture in South Brazil
}

\author{
SIMONE BENEDET FONTOURA ${ }^{1,2}$, GISLENE GANADE ${ }^{1,4}$ and JOÃO LAROCCA ${ }^{3}$
}

(received: May 5, 2005; accepted: January 5, 2006)

\begin{abstract}
Changes in plant community diversity and composition across an edge between Araucaria forest and pasture in South Brazil). This work investigated how richness, abundance, composition and structure of woody and herbaceous vegetation were altered by the proximity of an edge between Araucaria forest and pasture in South Brazil. Herbaceous and woody species including seedlings were surveyed in 42 plots of $5 \times 5 \mathrm{~m}$ randomly placed at the following distances: 5 and $50 \mathrm{~m}$ from the edge into the pasture and 0,25, 50, 100 and $250 \mathrm{~m}$ from the edge into the forest. There was a significant increase in vegetation cover, richness and abundance of woody species, woody seedlings and herbaceous plants at the edge $(0 \mathrm{~m})$. These variables, in general, decreased from 25 to $50 \mathrm{~m}$ from the edge into the forest in comparison to the forest interior. Few seedlings of woody plants were able to establish themselves in the pasture. There were continuous changes in species composition that occurred in the studied gradient due to the invasion of light-demanding species and the disappearance of some shade-tolerant species at the edge. In conclusion, the forest edge studied generated changes in the plant community that extended up to $50 \mathrm{~m}$ into the forest.
\end{abstract}

Key words - edge effects, herbaceous vegetation, seedling diversity, tree species composition, woody plants richness

RESUMO -(Mudanças na composição e diversidade de uma comunidade de plantas ao longo de uma borda entre floresta com araucária e pastagem no Sul do Brasil). Neste estudo investigamos como riqueza, abundância, composição e estrutura da vegetação lenhosa e herbácea foram alteradas pela proximidade de uma borda entre floresta com araucária e pastagem no sul do Brasil. Espécies lenhosas e herbáceas, incluindo plântulas, foram analisadas em 42 parcelas de $5 \times 5$ m dispostas aleatoriamente nas seguintes distâncias: 5 e $50 \mathrm{~m}$ da borda para dentro do campo e 0, 25, 50, 100 e $250 \mathrm{~m}$ da borda para dentro da floresta. Houve um aumento significativo na cobertura da vegetação, riqueza e abundância de espécies lenhosas, plântulas lenhosas e plantas herbáceas na borda $(0 \mathrm{~m})$. Essas variáveis, em geral, decresceram nas distâncias 25 a $50 \mathrm{~m}$ da borda para dentro da floresta em relação ao interior da mesma. Poucas plântulas lenhosas foram capazes de estabelecer-se no campo. Houve uma mudança contínua na composição de espécies que ocorreu no gradiente de borda devido à invasão de espécies heliófilas e o desaparecimento de alguma espécies tolerantes à sombra na borda. Concluímos que a comunidade de plantas encontra-se alterada na borda florestal estudada em uma extensão que vai até $50 \mathrm{~m}$ para dentro da floresta.

Palavras-chave - composição de espécies arbóreas, diversidade de plântulas, efeito de borda, riqueza de plantas lenhosas, vegetação herbácea

\section{Introduction}

The creation of an interface between forest and deforested areas can lead to sudden changes in the environmental conditions of these forests, here referred to as "edge effects" (Murcia 1995). These changes begin with the development of microclimatic gradients where the influence zone of the edge presents a greater exposure to winds, higher temperatures, lower humidity

\footnotetext{
1. Universidade do Vale do Rio dos Sinos (UNISINOS), Biologia, Laboratório de Ecologia da Restauração, Caixa Postal 275, 93001-970 São Leopoldo, RS, Brasil.

2. Programa de Pós Graduação em Ecologia, Instituto Nacional de Pesquisas da Amazônia (INPA), Manaus, AM, Brasil.

3. Universidade do Vale do Rio dos Sinos (UNISINOS), Biologia, Laboratório de Taxonomia Vegetal.

4._Corresponding author: gganade@unisinos.br
}

and higher sun radiation (Kapos 1989, Matlack 1993, Camargo \& Kapos 1995, Kapos et al. 1997, DaviesColley et al. 2000, Redding et al. 2003). These altered conditions can extend up to $100 \mathrm{~m}$ into the forest (Young \& Mitchell 1994).

Such environmental changes associated with forest edges can negatively affect the plant community that survives in forest remnants (Williams-Linera 1990a, Laurance \& Bierregaard 1996, Gehlhausen et al. 2000, Harper \& Macdonald 2002, Meiners et al. 2002). Some studies have demonstrated that the proximity to a forest edge may cause a greater tree mortality rate (Laurance et al. 1998, Laurance et al. 2000), changes in vegetation structure (Williams-Linera 1990a, Brothers \& Spingarn 1992, Malcolm 1994, Didham \& Lawton 1999, Honnay et al. 2002) and a reduction in the abundance of woody seedlings (Benitez-Malvido 1998). Additionally, in the long run, forest edges could alter the composition and 
abundance of pollinators, dispersers and potential seed predators which could affect the composition and structure of plant communities (Aizen \& Feinsinger 1994, Gascon et al. 1999, Restrepo \& Vargas 1999, Galetti et al. 2003, Kollmann \& Buschor 2003).

The Araucaria forest in South Brazil is composed of species from tropical and temperate floras. The Brazilian pine Araucaria angustifolia (Bertol.) Küntze is a key species defining its physiognomic features (Rambo 1956). Theses forests quite frequently have interfaces with savanna fields (Teixeira et al. 1986). In the past 5000 years Araucaria forests has expanded towards the fields and its expansion coincided with a lower fire frequency (Behling et al. 2004). Since the last century, fields have been converted in pastures for cattle ranching and frequently managed with fire. This and other anthropogenic conversions of land led to the destruction and fragmentation of Araucaria forests, which currently occupy only about $20 \%$ of its original range (Secretaria Estadual do Meio Ambiente 2001). To date, there is little knowledge about how fragmentation and edge effects could affect plant diversity, community structure and composition of Araucaria forest remnants.

This work investigates how an edge between Araucaria forest and pasture could influence the structure, richness, abundance and composition of woody and herbaceous plants established along this gradient.

\section{Material and methods}

Study area - The study area is located at the National Forest of São Francisco de Paula, Rio Grande do Sul State, southern Brazil, at the altitude of $912 \mathrm{~m}$ over the sea level. The climate of the region is Wet Temperate with well-distributed rainfalls during the year (Köppen 1936). Mean temperature in São Francisco de Paula is $14.5^{\circ} \mathrm{C}$; mean rainfall is $2,252 \mathrm{~mm} \mathrm{y}^{-1}$ (Backes 1999). The study site is located along an edge between a forest fragment and a pasture $\left(29^{\circ} 23^{\prime}-29^{\circ} 27^{\prime} \mathrm{S}\right.$ and $\left.50^{\circ} 23^{\prime}-50^{\circ} 25^{\prime} \mathrm{W}\right)$. The pasture has been managed for more than 50 years through the action of cattle and fire and these activities were suspended five years before the start of this study.

Sampling design - The study was performed at each of the following seven distances from the forest edge: $0 \mathrm{~m}$ (edge), $25,50,100$ and $250 \mathrm{~m}$ from the edge into the forest and 5 and $50 \mathrm{~m}$ from the edge into the pasture. In each distance, the plant community was sampled in six plots of $5 \times 5$ m randomly placed within a $100 \mathrm{~m}$ long transect. We sampled 42 plots in total (figure 1). In each plot sampled in the forest, all rooted woody plants $\geq 0.5 \mathrm{~m}$ in height were identified or collected for later identification. Seedlings of woody species and herbaceous plants $<0.5 \mathrm{~m}$ in height were sampled in $1 \times 1 \mathrm{~m}$ sub-plots placed inside each $5 \times 5 \mathrm{~m}$ plot. In cases where the complete identification was not possible, individuals were separated in morphospecies. All woody species $<0.5 \mathrm{~m}$ in height were considered seedlings. To investigate how species distribution along the studied gradient vary according to life form and light requirement, the studied distances were separated into three categories: field (-50 m and $-5 \mathrm{~m})$, edge $(0 \mathrm{~m}, 25 \mathrm{~m}$ and $50 \mathrm{~m})$ and forest $(100 \mathrm{~m}$ and $250 \mathrm{~m})$. Seedlings that were too young to be identified or classified according to their light requirement were not considered for this analysis. These individuals represented $24 \%$ of the total number of seedlings sampled. To identify the structural parameters that were altered due to the forest edge, we estimated: understory vegetation cover, soil vegetation cover and maximum canopy height. The understory vegetation cover was estimated according to Malcolm (1994), using a $3 \mathrm{~m}$ long pole that was placed every meter inside each $5 \times 5 \mathrm{~m}$ plot, with a total of 25 points sampled per plot. In each sampled point we registered the number of times the vegetation of the plot touched the pole. Soil vegetation cover was measured in each $1 \times 1 \mathrm{~m}$ sub-plot by a visual estimation of the amount of vegetation that cover the soil using the following percentage categories: 0 to 20,21 to 40,41 to 60,61 to 80 and 81 to 100 . Canopy height was estimated visually using a $2 \mathrm{~m}$ long calibration pole as parameter. Species were classified according to their light requirement using information provided by the published Flora Ilustrada Catarinense (Reitz 1965 to 1989). When this information was not available in Reitz (1965-1989) light requirement information was assigned using herbaria data and previous field work experience.

Data analysis - To evaluate possible alterations in floristic composition of woody, seedlings and herbaceous species along the edge gradient studied we performed separate cluster analysis for each life form using the single linkage method.

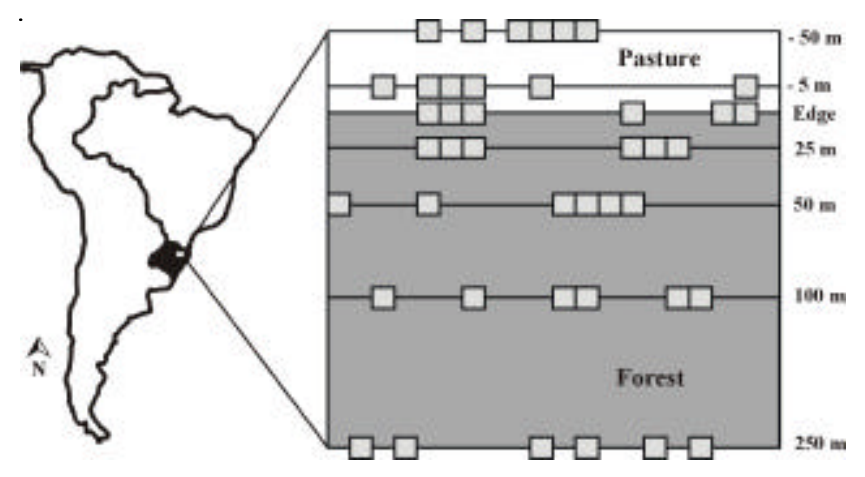

Figure 1. Study site and sampling design of vegetation survey performed along the edge gradient studied. Quadrats represent the $5 \times 5 \mathrm{~m}$ plots randomly assigned in each distance: $-50 \mathrm{~m}$ and $-5 \mathrm{~m}$ from the edge into the field and $0 \mathrm{~m}$, $25 \mathrm{~m}, 50 \mathrm{~m}, 100 \mathrm{~m}$ and $250 \mathrm{~m}$ from the edge into the forest. The study was performed at the National Forest of São Francisco de Paula, Rio Grande do Sul State, South Brazil. 
The Euclidian Distance was used for measurements of species relative abundance, while species presence and absence were analysed using the Percent Distance Index. Species richness and the abundance of individuals in each plant category were compared among the different distances from the edge by ANOVA, using the a posteriori test of Tukey (Zar 1984).

\section{Results}

During the survey 2,040 individuals were sampled and 106 species were recognized (69 genera, 45 families and 22 morphospecies of vascular plants) (table 1). The forest edge and the pasture contained a greater

Table 1. Taxonomical list of species sampled in the study area. Life forms represent: canopy tree (CT); sub-canopy tree (ST); shrub $(\mathrm{SH})$, herb (HB) and probably canopy-tree (PCT). Light requirement represents: $\mathrm{L}=$ light demanding; $\mathrm{S}=$ shade tolerant and $\mathrm{I}=$ indifferent.

\begin{tabular}{|c|c|c|c|c|c|}
\hline Family/Species & $\begin{array}{l}\text { Life } \\
\text { form }\end{array}$ & $\begin{array}{l}\text { Light } \\
\text { requirement }\end{array}$ & Family/Species & $\begin{array}{l}\text { Life } \\
\text { form }\end{array}$ & $\begin{array}{l}\text { Light } \\
\text { requirement }\end{array}$ \\
\hline AMARANTHACEAE & & & COMMELLINACEAE & & \\
\hline Gomphrena sp. & $\mathrm{HB}$ & $\mathrm{L}$ & Commellinaceae 1 & PCT & \\
\hline ANACARDIACEAE & & & CONVOLVULACEAE & & \\
\hline Lithraea brasiliensis Marchand & CT & I & Dichondra sp. & $\mathrm{HB}$ & $\mathrm{L}$ \\
\hline ANONNACEAE & & & CUNONIACEAE & & \\
\hline Rollinia sylvatica (A. St.-Hil.) Mart. & ST & I & Lamanonia ternata Vell. & $\mathrm{CT}$ & $\mathrm{L}$ \\
\hline APIACEAE & & & DENNSTAEDTIACEAE & & \\
\hline Eryngium horridum Malme & $\mathrm{HB}$ & $\mathrm{L}$ & Pteridium aquilinum (L.) Kuhn & $\mathrm{HB}$ & $\mathrm{L}$ \\
\hline Hydrocotyle sp. & $\mathrm{HB}$ & $\mathrm{S}$ & ESCALLONIACEAE & & \\
\hline Apiaceae 1 & $\mathrm{HB}$ & & Escallonia bifida Link \& Otto & ST & $\mathrm{L}$ \\
\hline AQUIFOLIACEAE & & & EUPHORBIACEAE & & \\
\hline Ilex cf. microdonta Reissek & ST & $\begin{array}{l}S \\
c\end{array}$ & Sapium glandulatum (Vell.) Pax & CT & $\mathrm{L}$ \\
\hline Ilex paraguariensis A. St.-Hil. & CT & S & Sebastiania brasiliensis Spreng. & ST & $\mathrm{L}$ \\
\hline $\begin{array}{l}\text { ARALIACEAE } \\
\text { Oreopanax fulvum Marchal }\end{array}$ & $\mathrm{CT}$ & $S$ & Stillingia oppositifolia Baill. ex Müll. Arg. & ST & $\mathrm{S}$ \\
\hline ARAUCARIACEAE & & $S$ & Sebastiania sp. & ST & $\mathrm{L}$ \\
\hline Araucaria angustifolia (Bertol.) Kuntze & CT & I & FLACOURTIACEAE & & \\
\hline ASCLEPIADACEAE & & & Casearia decandra Jacq. & ST & I \\
\hline Asclepias curassavica $\mathrm{L}$. & $\mathrm{HB}$ & $\mathrm{L}$ & Xylosma cf. tweediana (Clos) Eichl. & ST & $\mathrm{L}$ \\
\hline ASPLENIACEAE & & & Xylosma sp. & ST & $\mathrm{L}$ \\
\hline Asplenium sp. & $\mathrm{HB}$ & $S$ & LAMIACEAE & & \\
\hline ASTERACEAE & & & Glechon sp. & $\mathrm{HB}$ & $\mathrm{L}$ \\
\hline Achyrocline satureioides (Lam.) DC. & $\mathrm{HB}$ & $\mathrm{L}$ & LAURACEAE & & \\
\hline Chaptalia nutans (L.) Pol. & $\mathrm{HB}$ & $\mathrm{L}$ & Cinnamoтит атоепит (Nees) Kosterm & CT & $\mathrm{S}$ \\
\hline Elephantopus mollis Kunth & $\mathrm{HB}$ & I & Cryptocarya cf. moschata Ness \& Mart. & t. CT & $S$ \\
\hline Piptocarpha notata (Less.) Baker & SH & $\mathrm{L}$ & Ocotea lancifolia (Schott) $\mathrm{Mez}$ & CT & $\mathrm{S}$ \\
\hline Solidago chilensis Meyen & $\mathrm{HB}$ & $\mathrm{L}$ & Lauraceae 1 & PCT & \\
\hline Vernonia cf. flexuosa Sims & $\mathrm{HB}$ & $\mathrm{L}$ & LOGANIACEAE & & \\
\hline Baccharis sp.1 & $\mathrm{HB}$ & $\mathrm{L}$ & Strychnos brasiliensis (Spreng.) Mart. & SH & $\mathrm{L}$ \\
\hline Baccharis sp.2 & $\mathrm{SH}$ & $\mathrm{L}$ & MELASTOMATACEAE & & \\
\hline Eupatorium sp.1 & SH & $\mathrm{L}$ & Miconia cinerascens Miq. & SH & $\mathrm{L}$ \\
\hline Eupatorium sp.2 & SH & $\mathrm{L}$ & Tibouchina gracilis (Bonpl.) Cogn. & $\mathrm{HB}$ & $\mathrm{L}$ \\
\hline Pterocaulon sp. & $\mathrm{HB}$ & $\mathrm{L}$ & MIMOSACEAE & & \\
\hline BERBERIDACEAE & & & Desmanthus virgatus (L.) Willd. & SH & $\mathrm{L}$ \\
\hline Berberis laurina Billb. & $\mathrm{SH}$ & $\mathrm{L}$ & MONIMIACEAE & & \\
\hline CAMPANULACEAE & & & Mollinedia elegans Tul. & SH & $\mathrm{S}$ \\
\hline Triodanis biflora (Ruiz \& Pav.) Greene & $\mathrm{HB}$ & $\mathrm{L}$ & MYRSINACEAE & & \\
\hline CELASTRACEAE & & & Myrsine umbellata Mart. & $\mathrm{CT}$ & $\mathrm{L}$ \\
\hline Maytenus aquifolium Mart. & ST & $\mathrm{L}$ & Myrsine sp. & CT & $\begin{array}{c}\mathrm{L} \\
\text { continue }\end{array}$ \\
\hline
\end{tabular}




\begin{tabular}{|c|c|c|c|c|c|}
\hline Family/Species & $\begin{array}{l}\text { Life } \\
\text { form }\end{array}$ & $\begin{array}{l}\text { Light } \\
\text { requirement }\end{array}$ & Family/Species & $\begin{array}{l}\text { Life } \\
\text { form } 1\end{array}$ & $\begin{array}{l}\text { Light } \\
\text { requirement }\end{array}$ \\
\hline \multicolumn{3}{|l|}{ MYRTACEAE } & RUTACEAE & \multirow{3}{*}{ CT } & \multirow{3}{*}{ I } \\
\hline Acca sellowiana (O. Berg) Burret & CT & $\mathrm{L}$ & Zanthoxylum rhoifolium Lam. & & \\
\hline Eugenia psidiiflora O. Berg & ST & $\mathrm{S}$ & SAPINDACEAE & & \\
\hline Calyptranthes concinna DC. & ST & $\mathrm{L}$ & \multirow{2}{*}{$\begin{array}{l}\text { Allophylus edulis (A. St.Hil., Cambess. } \\
\text { \& A. Juss.) Radlk. }\end{array}$} & \multirow[t]{2}{*}{$\mathrm{ST}$} & \multirow[t]{2}{*}{$\mathrm{I}$} \\
\hline Campomanesia xanthocarpa O. Berg & CT & $\mathrm{L}$ & & & \\
\hline Myrceugenia myrcioides (Cambess.) & ST & $\mathrm{S}$ & Cupania vernalis Cambess. & CT & $\mathrm{L}$ \\
\hline $\begin{array}{l}\text { O. Berg } \\
\text { Myrcia oligantha } \mathrm{O} . \text { Berg }\end{array}$ & ST & I & Matayba elaeagnoides Radlk. & $\mathrm{CT}$ & I \\
\hline $\begin{array}{l}\text { Myrcla ollganina } \mathrm{U} \text {. Berg } \\
\text { Myrrhinium atropurpureum Schott }\end{array}$ & ST & I & \multicolumn{3}{|l|}{ SOLANACEAE } \\
\hline Siphoneugena reitzii D. Legrand & ST & $\mathrm{L}$ & Solanum americanum Mill. & \multirow{3}{*}{$\begin{array}{l}\mathrm{HB} \\
\mathrm{SH}\end{array}$} & \multirow{3}{*}{$\begin{array}{l}\mathrm{L} \\
\mathrm{S}\end{array}$} \\
\hline Myrceugenia sp. & ST & $\mathrm{S}$ & Brunfelsia sp. & & \\
\hline Myrtaceae 1 & PCT & & SYMPLOCACEAE & & \\
\hline Myrtaceae 2 & PCT & & Symplocos uniflora (Pohl) Benth. & \multirow[t]{2}{*}{ ST } & \multirow[t]{2}{*}{$\mathrm{L}$} \\
\hline Myrtaceae 3 & PCT & & THEACEAE & & \\
\hline Myrtaceae 4 & PCT & & Gordonia fruticosa (Schrad.) H. Keng & \multirow[t]{2}{*}{$\mathrm{ST}$} & \multirow[t]{2}{*}{$\mathrm{S}$} \\
\hline ORCHIDACEAE & & & THELIPTERIDACEAE & & \\
\hline Orchidaceae 1 & $\mathrm{HB}$ & & Thelipteris sp. & \multirow[t]{2}{*}{$\mathrm{HB}$} & \multirow[t]{2}{*}{$\mathrm{I}$} \\
\hline OXALIDACEAE & & & THYMELAEACEAE & & \\
\hline Oxalis sp.1 & $\mathrm{HB}$ & $\mathrm{L}$ & Daphnopsis racemosa Griseb. & \multirow[t]{2}{*}{ SH } & \multirow[t]{2}{*}{$\mathrm{I}$} \\
\hline Oxalis sp. 2 & $\mathrm{HB}$ & $\mathrm{L}$ & ULMACEAE & & \\
\hline PODOCARPACEAE & & & Celtis cf. iguanaea (Jacq.) Sarg. & \multirow[t]{2}{*}{ ST } & \multirow[t]{2}{*}{$\mathrm{L}$} \\
\hline $\begin{array}{l}\text { Podocarpus lambertii Klotzsch ex Endl. } \\
\text { POIYPODIACEAF }\end{array}$ & CT & $\mathrm{L}$ & VERBENACEAE & & \\
\hline $\begin{array}{l}\text { Polypodium sp. } \\
\text { Polypolate }\end{array}$ & $\mathrm{HB}$ & $S$ & Lippia ramboi Moldenke & \multirow[t]{2}{*}{ SH } & \multirow[t]{2}{*}{$\mathrm{L}$} \\
\hline PROTEACEAE & & & WINTERACEAE & & \\
\hline Roupala brasiliensis Klotzsch & $\mathrm{CT}$ & $\mathrm{S}$ & Drimys brasiliensis Miers & \multirow[t]{2}{*}{ ST } & \multirow[t]{2}{*}{ I } \\
\hline RHAMNACEAE & & & MORPHOSPECIES & & \\
\hline Rhamnus sphaerosperma Sw. & ST & $\mathrm{L}$ & Herbs $(1-5)$ & \multicolumn{2}{|l|}{$\mathrm{HB}$} \\
\hline RUBIACEAE & & & Woody $(1-6)$ & \multicolumn{2}{|l|}{ PCT } \\
\hline Rudgea parquioides (Cham.) Müll. Arg. & ST & $\mathrm{S}$ & Seedling $(1-11)$ & \multicolumn{2}{|l|}{ PCT } \\
\hline
\end{tabular}

abundance of light-demanding individuals than the forest interior, which had a dominance of shade-tolerant individuals (figure 2A). However, the proportion of light demanding species tended to be similar between forest and edge, although we found a trend for a higher proportion of light demanding species at the edge zone for most of the plant life forms studied (figure 2B). Plant species that were classified as indifferent in relation to their light requirements tended to be homogeneously distributed throughout the gradient. We found a greater abundance of trees at the edge than at the forest interior, moreover, sub-canopy trees were more frequent than canopy trees. At the pasture, herbs predominated; seedlings of woody species were scarce, and shrubs and trees were absent (figure 2A).

Woody species - There was a higher abundance $\left(F_{4.25}=7.5, P<0.001\right.$, figure $\left.3 \mathrm{~A}\right)$ and richness
$\left(F_{4.25}=5.09, P<0.01\right.$, figure 3B $)$ of woody species at the edge $(0 \mathrm{~m})$ in relation to the distances 25 and $50 \mathrm{~m}$ from the edge into the forest. The cluster analysis revealed a continuous change in woody species composition along the edge gradient studied for both abundance and presence/absence (figure 5A). The greatest similarity occurred between the distances $100 \mathrm{~m}$ and $250 \mathrm{~m}$ into the forest. The forest interior was then more similar to the distance $50 \mathrm{~m}$ followed by the distance $25 \mathrm{~m}$ from the edge towards the forest. The edge $(0 \mathrm{~m})$ contained a distinct composition of woody plant species in relation to all other distances studied. We found 56 taxa of woody plants (table 2). The most abundant woody species were Stillingia oppositifolia (350 individuals), Siphoneugena reitzii (265), Rudgea parquioides (170) and Casearia decandra (107). These species differed in their spatial distribution along 
the edge gradient. $S$. reitzii occurred more often near the edge, $S$. oppositifolia and $R$. parquioides tended to occur inside the forest $(100$ and $250 \mathrm{~m})$ while C. decandra was homogeneously distributed in all studied distances (table 2). Twelve woody species occurred exclusively at the edge $(0 \mathrm{~m})$ and five species occurred exclusively in the forest interior (100 and $250 \mathrm{~m}$ ), but these species tended to be rare. Sixteen species were able to use most of the studied gradient (table 2).

Seedlings - Seedling abundance $\left(F_{4.25}=6.4, P<0.01\right.$, figure 4A) and richness $\left(F_{4.25}=5.1, P<0.01\right.$, figure 4B) were significantly higher at the edge $(0 \mathrm{~m})$. Moreover, there was a sharp decrease in abundance at the pasture and the distance $25 \mathrm{~m}$ into the forest. The cluster analysis using abundance and presence/absence revealed clear alterations in species composition of seedlings at the edge $(0 \mathrm{~m})$ in relation to the pasture and forest interior. Moreover, three distinct groups were found: 1 ) the edge, $0 \mathrm{~m} ; 2$ ) the forest, made up by the distances $50 \mathrm{~m}, 100 \mathrm{~m}$
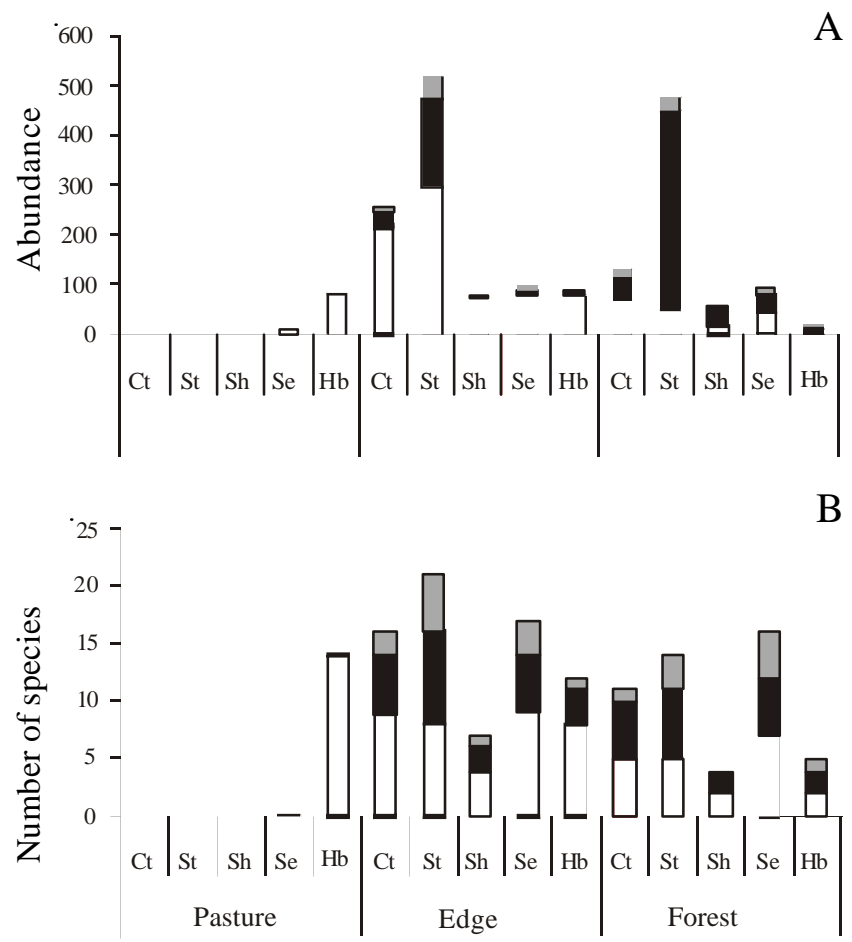

Figure 2. Number of individuals (A) and number of species (B) according to their light requirement ( $\square=$ light-demanding;

$\mathbf{\square}=$ shade-tolerant; $\mathbf{\square}=$ indifferent $)$, and life form $(\mathrm{Ct}=$ tree; $\mathrm{St}=$ small tree; $\mathrm{Sh}=$ shrub; $\mathrm{Se}=$ seedling; $\mathrm{Hb}=$ herb) found along the three main environmental categories studied: pasture, edge and forest. The study was performed at the National Forest of São Francisco de Paula, Rio Grande do Sul State, South Brazil.
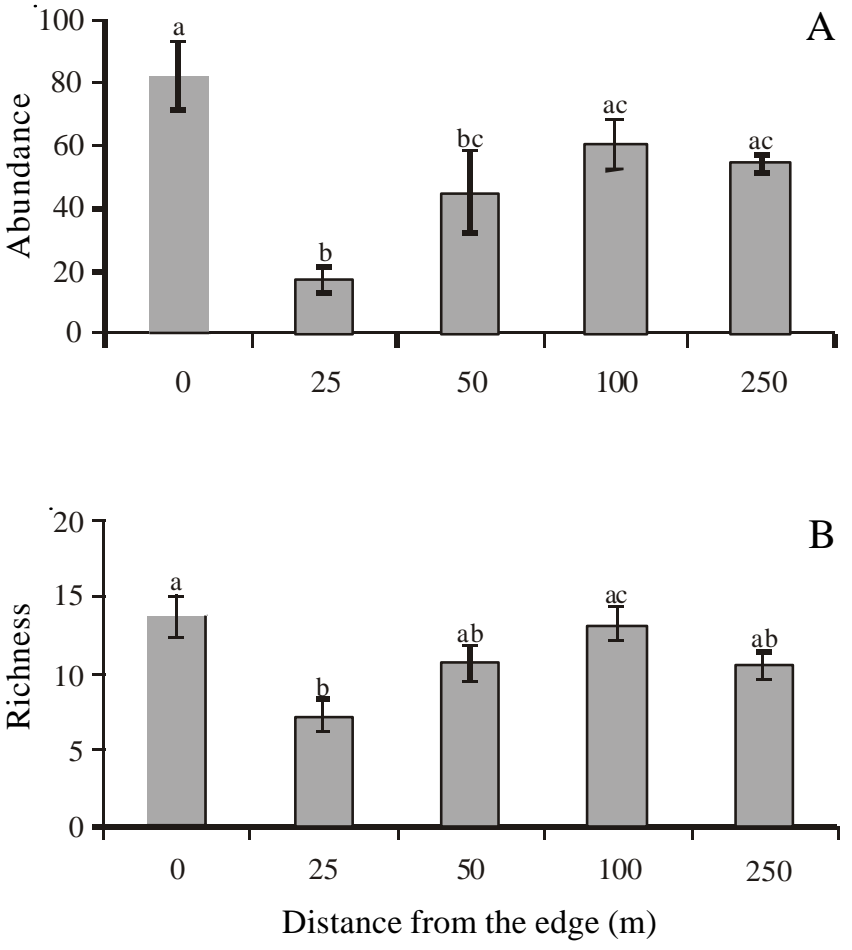

Figure 3. Abundance (A) and richness (B) of woody plants (mean \pm 1 standard error) at different distances from the forest edge. Distinct letters indicate significant differences among distances. The study was performed at the National Forest of São Francisco de Paula, Rio Grande do Sul State, South Brazil.

and $250 \mathrm{~m}$ and 3) the distances $-50 \mathrm{~m},-5 \mathrm{~m}$ (pasture) and $25 \mathrm{~m}$ (figure 5B). We found 41 taxa of woody seedlings (table 3 ). The most abundant seedling species that occurred were Siphoneugena reitzii (29 individuals), Myrsine sp. (25), Seedling 1 (23) and Stillingia oppositifolia (23). S. reitzii and S. oppositifolia coincided with the most abundant adult species (table 3). Six species of seedlings were able to establish in the pasture, occurring exclusively at this area: Escallonia bifida, Baccharis sp.2, Desmanthus virgatus, Eupatorium sp.1 and Eupatorium sp.2 all typical pioneer species, and Podocarpus lambertii, a light-demanding tree that frequently occurs inside the forest. Six morphospecies occurred exclusively at the edge $(0 \mathrm{~m})$, five exclusively inside the forest at 100 and $250 \mathrm{~m}$, and 14 species occurred along the whole gradient between edge and forest interior (table 3 ).

Herbaceous plants - The abundance of herbaceous plants was significantly greater at the edge $(0 \mathrm{~m})$ in relation to all other considered distances, with sharp decreases in the field and inside the forest $\left(F_{4.25}=4.2\right.$, $P<0.01$, figure 4C). Richness of herbaceous plants was greater in the field and at the edge $(0 \mathrm{~m})$, decreasing 
Table 2. Percentage of individuals of woody species in relation to the total number of individuals per species (Total) occurring at the following distances from the forest edge: $0 \mathrm{~m}, 25 \mathrm{~m}, 50 \mathrm{~m}, 100 \mathrm{~m}$ and $250 \mathrm{~m}$. Light requirements are: $\mathrm{L}=$ light demanding; $\mathrm{S}=$ shade tolerant and $\mathrm{I}=$ indifferent.

\begin{tabular}{|c|c|c|c|c|c|c|c|}
\hline \multirow[t]{2}{*}{ Species } & \multirow[b]{2}{*}{ Light requirement } & \multicolumn{5}{|c|}{ Individuals for each distance $(\%)$} & \multirow[b]{2}{*}{ Total } \\
\hline & & $0 \mathrm{~m}$ & $25 \mathrm{~m}$ & $50 \mathrm{~m}$ & $100 \mathrm{~m}$ & $250 \mathrm{~m}$ & \\
\hline Acca sellowiana & $\mathrm{L}$ & 100 & & & & & 2 \\
\hline Allophylus edulis & $\mathrm{S}$ & 100 & & & & & 8 \\
\hline Berberis laurina & $\mathrm{L}$ & 100 & & & & & 3 \\
\hline Celtis cf. iguanaea & $\mathrm{L}$ & 100 & & & & & 1 \\
\hline Ilex cf. microdonta & $\mathrm{S}$ & 100 & & & & & 2 \\
\hline Lithraea brasiliensis & I & 100 & & & & & 7 \\
\hline Rhamnus sphaerosperma & $\mathrm{L}$ & 100 & & & & & 1 \\
\hline Sapium glandulatum & $\mathrm{L}$ & 100 & & & & & 2 \\
\hline Symplocos uniflora & $\mathrm{L}$ & 100 & & & & & 2 \\
\hline Woody 3 & & 100 & & & & & 1 \\
\hline Woody 4 & & 100 & & & & & 1 \\
\hline Woody 5 & & 100 & & & & & 1 \\
\hline Lamanonia ternata & $\mathrm{L}$ & & 100 & & & & 2 \\
\hline Myrtaceae 2 & & & 100 & & & & 3 \\
\hline Cinnamomum cf. amoenum & $\mathrm{S}$ & & & 100 & & & 1 \\
\hline Myrtaceae 4 & & & & 100 & & & 1 \\
\hline Oreopanax fulvum & $S$ & & & & 100 & & 1 \\
\hline Woody 1 & & & & & 100 & & 2 \\
\hline Woody 2 & & & & & 100 & & 1 \\
\hline Woody 6 & & & & & 100 & & 1 \\
\hline Xylosma sp. & $\mathrm{L}$ & & & & & 100 & 3 \\
\hline Piptocarpha notata & $\mathrm{L}$ & 80 & 20 & & & & 5 \\
\hline Daphnopsis racemosa & $\mathrm{I}$ & 50 & 50 & & & & 8 \\
\hline Drimys brasiliensis & I & 50 & 50 & & & & 2 \\
\hline Myrsine umbellata & $\mathrm{L}$ & 90 & & 10 & & & 29 \\
\hline Rollinia sylvatica & I & 62 & 31 & 8 & & & 13 \\
\hline Calyptranthes concinna & $\mathrm{L}$ & 64 & 18 & 9 & 9 & & 11 \\
\hline Araucaria angustifolia & $\mathrm{L}$ & 57 & 7 & 25 & 11 & & 28 \\
\hline Lippia ramboi & $\mathrm{L}$ & 86 & & & & 14 & 7 \\
\hline Siphoneugena reitzii & $\mathrm{L}$ & 82 & 4 & 9 & 4 & 2 & 265 \\
\hline Podocarpus lambertii & $\mathrm{L}$ & 56 & 12 & 20 & 8 & 4 & 25 \\
\hline Myrsine sp. & $\mathrm{L}$ & 65 & 7 & 4 & 22 & 2 & 91 \\
\hline Ocotea lancifolia & $\mathrm{S}$ & 56 & 11 & 11 & 17 & 6 & 18 \\
\hline Miconia cinerascens & $\mathrm{L}$ & 66 & 4 & 7 & 16 & 8 & 76 \\
\hline Myrrhinium atropurpureum & $\mathrm{I}$ & 35 & 6 & 47 & 12 & & 17 \\
\hline Casearia decandra & $\mathrm{I}$ & 19 & 21 & 17 & 33 & 10 & 107 \\
\hline Rudgea parquioides & $\mathrm{S}$ & 5 & 13 & 9 & 31 & 42 & 170 \\
\hline Xylosma cf. tweedianum & $\mathrm{L}$ & 33 & & 67 & & & 3 \\
\hline Myrceugenia myrcioides & $\mathrm{S}$ & 13 & & & 50 & 38 & 8 \\
\hline Myrcia oligantha & $\mathrm{I}$ & 6 & 6 & 33 & & 56 & 18 \\
\hline Ilex paraguariensis & $\mathrm{S}$ & 33 & & & & 67 & 3 \\
\hline Gordonia fruticosa & $\mathrm{S}$ & 20 & & & 60 & 20 & 5 \\
\hline Cryptocarya cf. moschata & $\mathrm{S}$ & & & 60 & 20 & 20 & 10 \\
\hline Eugenia psidiiflora & $\mathrm{S}$ & & 31 & 15 & 23 & 31 & 26 \\
\hline Campomanesia xanthocarpa & $\mathrm{L}$ & & & 84 & 8 & 8 & 37 \\
\hline Myrtaceae 3 & & & 25 & 17 & 50 & 8 & 12 \\
\hline Mollinedia elegans & $\mathrm{S}$ & & 3 & & 50 & 47 & 32 \\
\hline
\end{tabular}


continuation

\begin{tabular}{|c|c|c|c|c|c|c|c|}
\hline \multirow[t]{2}{*}{ Species } & \multirow[b]{2}{*}{ Light requirement } & \multicolumn{5}{|c|}{ Individuals for each distance $(\%)$} & \multirow[b]{2}{*}{ Total } \\
\hline & & $0 \mathrm{~m}$ & $25 \mathrm{~m}$ & $50 \mathrm{~m}$ & $100 \mathrm{~m}$ & $250 \mathrm{~m}$ & \\
\hline Stillingia oppositifolia & $\mathrm{S}$ & & & 29 & 34 & 37 & 350 \\
\hline Roupala brasiliensis & $\mathrm{S}$ & & & 26 & 42 & 32 & 31 \\
\hline Sebastiania brasiliensis & $\mathrm{L}$ & & & 20 & 43 & 37 & 30 \\
\hline Myrceugenia sp. & $\mathrm{S}$ & & & 6 & 65 & 29 & 17 \\
\hline Matayba elaeagnoides & $\mathrm{I}$ & & & 17 & 54 & 29 & 24 \\
\hline Cupania vernalis & $\mathrm{L}$ & & & 25 & 25 & 50 & 4 \\
\hline Maytenus aquifolium & $\mathrm{L}$ & & & 33 & & 67 & 3 \\
\hline Brunfelsia sp. & $\mathrm{S}$ & & & 9 & & 91 & 11 \\
\hline Myrtaceae 1 & & & & & 50 & 50 & 2 \\
\hline
\end{tabular}

from $25 \mathrm{~m}$ on into the forest $\left(F_{4.25}=4.7, P<0.01\right)$, however, the Tukey test only detected a significant difference between the edge $(0 \mathrm{~m})$ and the distance $25 \mathrm{~m}$ into the forest (figure 4D). The cluster analysis for abundance and presence/absence demonstrated the occurrence of distinct assemblages of herbaceous plants at the edge $(0 \mathrm{~m})$ and $5 \mathrm{~m}$ inside the pasture. We found a greater similarity in the assemblages of herbaceous plants occurring inside the forest interior (figure 5C). We found 32 taxa of herbaceous plants (table 4). The most abundant herbaceous species that occurred on the area were Chaptalia nutans and Eryngium horridum. This species presented differences in their spatial distribution along the edge gradient, individuals of C. nutans occurred only in the forest, and $80 \%$ of them occurred at the edge $(0 \mathrm{~m})$. E. horridum, however, occurred only in the pasture (table 4). We registered 12 morphospecies that occurred exclusively in the pasture, 10 morphospecies prevailed at the edge $(0 \mathrm{~m})$ and only 4 morphospecies were found exclusively inside the

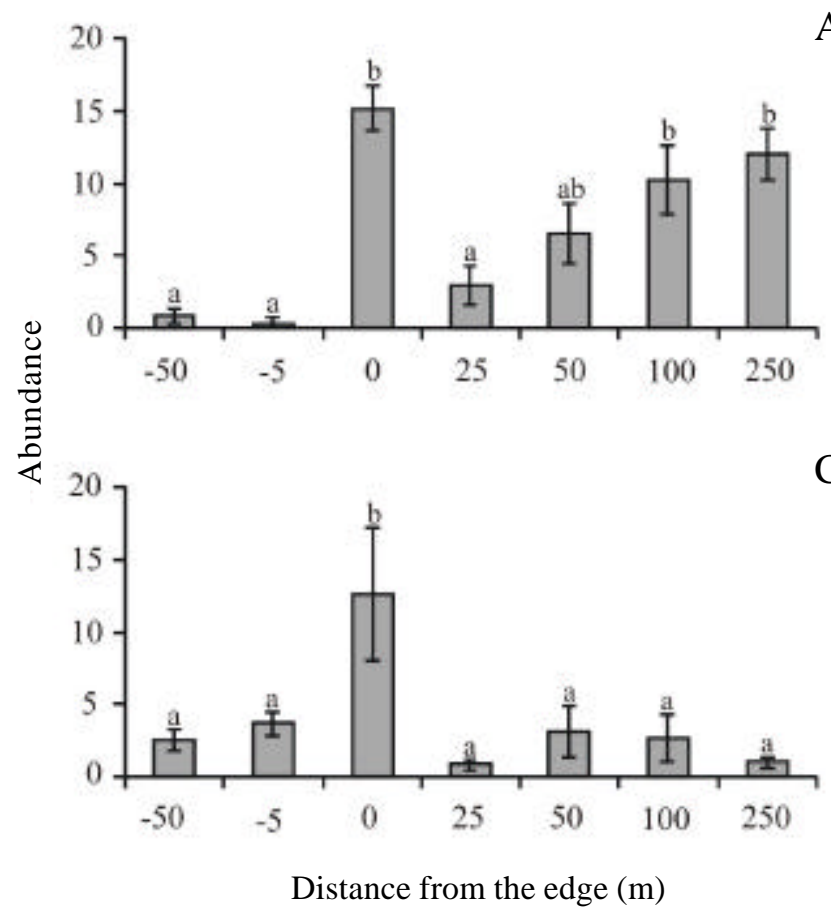

A

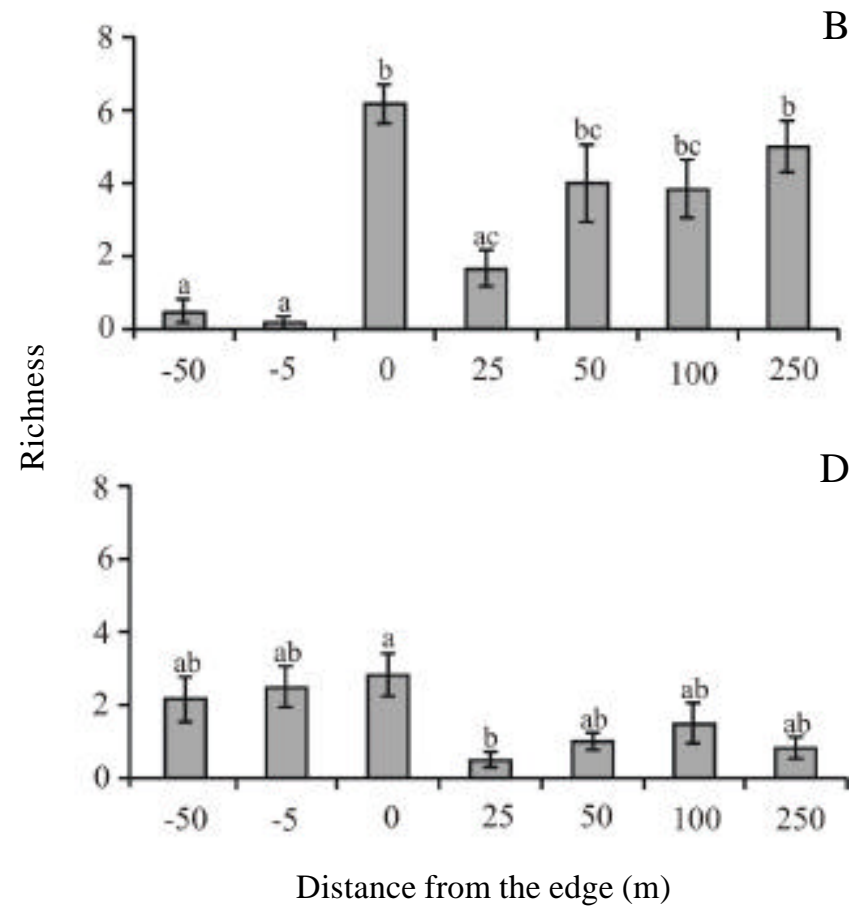

Figure 4. Abundance (A) and richness (B) of woody seedlings and abundance (C) and richness (D) of herbaceous plants (mean \pm 1 standard error) at different distances from a forest edge. Distinct letters indicate significant differences among distances. The study was performed at the National Forest of São Francisco de Paula, Rio Grande do Sul State, South Brazil. 
Abundance
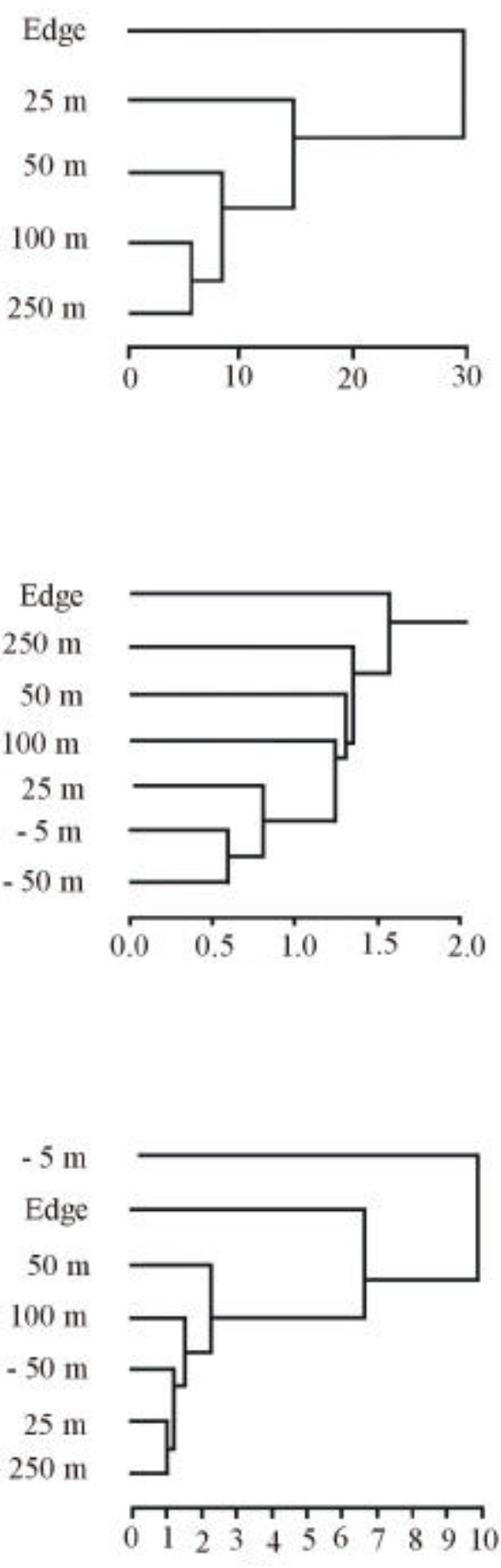

Distances
Presence/Absence

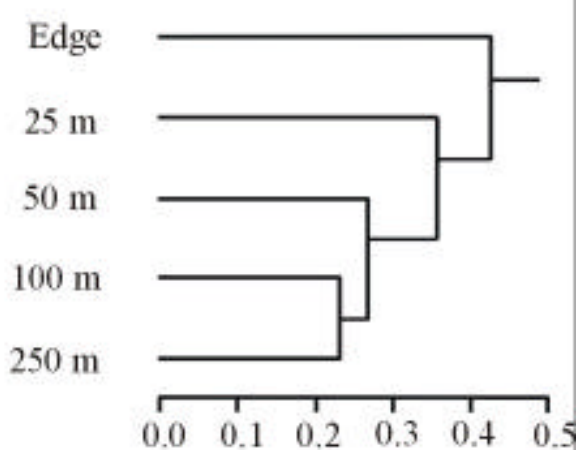

B

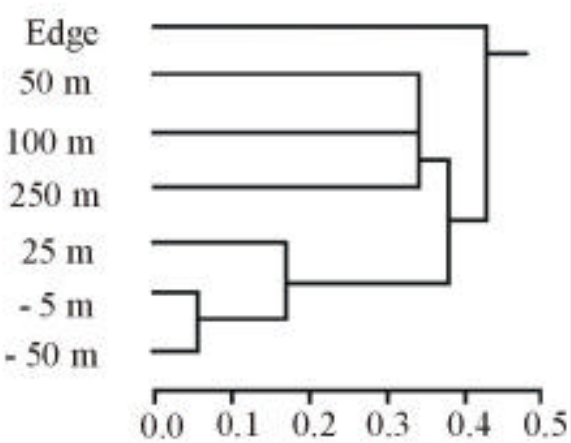

C

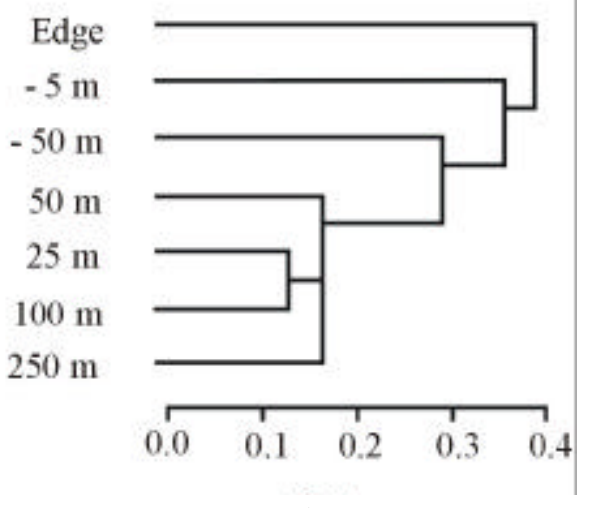

Distances

Figure 5. Cluster analysis looking at similarity by abundance and by presence/absence of species composition of Woody (A), Seedlings (B) and Herbs (C) at different distances from the forest edge. The study was performed at the National Forest of São Francisco de Paula, Rio Grande do Sul State, South Brazil. 
Table 3. Percentage of individuals of woody seedlings in relation to the total number of individuals per species (Total) occurring at the following distances from the forest edge: $0 \mathrm{~m}, 25 \mathrm{~m}, 50 \mathrm{~m}, 100 \mathrm{~m}$ and $250 \mathrm{~m}$. Light requirements are: $\mathrm{L}=$ light demanding; $\mathrm{S}=$ shade tolerant and $\mathrm{I}=$ indifferent.

\begin{tabular}{|c|c|c|c|c|c|c|c|c|c|}
\hline \multirow[t]{2}{*}{ Species } & \multirow[b]{2}{*}{ Light requirement } & \multicolumn{7}{|c|}{ Individuals for each distance (\%) } & \multirow[b]{2}{*}{ Tota } \\
\hline & & $-50 \mathrm{~m}$ & $-5 \mathrm{~m}$ & $0 \mathrm{~m}$ & $25 \mathrm{~m}$ & $50 \mathrm{~m}$ & $100 \mathrm{~m}$ & $250 \mathrm{~m}$ & \\
\hline Escallonia bifida & $\mathrm{L}$ & 100 & & & & & & & 2 \\
\hline Podocarpus lambertii & $\mathrm{L}$ & 100 & & & & & & & 2 \\
\hline Baccharis sp.2 & $\mathrm{L}$ & 50 & 50 & & & & & & 2 \\
\hline Desmanthus virgatus & $\mathrm{L}$ & 75 & 25 & & & & & & 4 \\
\hline Eupatorium sp.1 & $\mathrm{L}$ & 33 & 67 & & & & & & 3 \\
\hline Eupatorium sp.2 & $\mathrm{L}$ & & 100 & & & & & & 1 \\
\hline Calyptranthes concinna & $\mathrm{L}$ & & & 100 & & & & & 1 \\
\hline Lamanonia ternata & $\mathrm{L}$ & & & 100 & & & & & 5 \\
\hline Myrsine umbellata & $\mathrm{L}$ & & & 100 & & & & & 7 \\
\hline Sebastiania brasiliensis & $\mathrm{L}$ & & & 100 & & & & & 5 \\
\hline Seedling 2 & & & & 100 & & & & & 1 \\
\hline Comellinaceae 1 & & & & 100 & & & & & 1 \\
\hline Lauraceae 1 & & & & & 100 & & & & 1 \\
\hline Myrtaceae 2 & & & & & 100 & & & & 1 \\
\hline Allophylus edulis & $\mathrm{S}$ & & & & & 100 & & & 2 \\
\hline Zanthoxylum rhoifolium & I & & & & & 100 & & & 1 \\
\hline Seedling 11 & & & & & & 100 & & & 1 \\
\hline Cupania vernalis & $\mathrm{L}$ & & & & & & 100 & & 1 \\
\hline Sebastiania sp. & $\mathrm{L}$ & & & & & & 100 & & 12 \\
\hline Brunfelsia sp. & $\mathrm{S}$ & & & & & & & 100 & 2 \\
\hline Lithraea brasiliensis & I & & & & & & & 100 & 4 \\
\hline Seedling 9 & & & & & & & & 100 & 1 \\
\hline Myrrhinium atropurpureum & I & & & 35 & & 18 & & 47 & 17 \\
\hline Strychnos brasiliensis & $\mathrm{L}$ & & & 25 & & 13 & & 63 & 8 \\
\hline Seedling 5 & & & & 50 & & 50 & & & 2 \\
\hline Ocotea lancifolia & $\mathrm{S}$ & & & 33 & & & 33 & 33 & 6 \\
\hline Miconia cinerascens & $\mathrm{L}$ & & & 50 & & & 43 & 7 & 14 \\
\hline Myrsine sp. & $\mathrm{L}$ & & & 44 & 16 & 8 & 32 & & 25 \\
\hline Seedling 1 & & & & 26 & 17 & 9 & & 48 & 23 \\
\hline Campomanesia xanthocarpa & $\mathrm{L}$ & & & 17 & & 50 & 6 & 28 & 18 \\
\hline Rudgea parquioides & $S$ & & & 20 & & 20 & 40 & 20 & 5 \\
\hline Seedling 6 & & & & 6 & & 18 & 41 & 35 & 17 \\
\hline Siphoneugena reitzii & $\mathrm{L}$ & & & 79 & & & 10 & 10 & 29 \\
\hline Casearia decandra & I & & & 60 & & & 40 & & 5 \\
\hline Seedling 8 & & & & & 40 & 20 & & 40 & 5 \\
\hline Seedling 7 & & & & & 33 & 67 & & & 3 \\
\hline Roupala brasiliensis & $\mathrm{S}$ & & & & & 20 & 40 & 40 & 5 \\
\hline Seedling 4 & & & & & & 67 & & 33 & 3 \\
\hline Stillingia oppositifolia & $\mathrm{S}$ & & & & & 9 & 57 & 35 & 23 \\
\hline Seedling 3 & & & & & & 67 & 33 & & 3 \\
\hline Seedling 10 & & & & & & 50 & 50 & & 2 \\
\hline
\end{tabular}

forest. Two morphospecies found in the field were able to invade the forest edge and only Pteridium aquilinum was able to occur in the pasture and in the forest interior (table 4).

Structural parameters - There was a significant increase in vegetation cover of understory plants at the edge $(0 \mathrm{~m})$ in relation to the other distances studied in the forest $\left(F_{4.25}=10.3, P<0.001\right.$, figure 6A). However, neither canopy height $\left(F_{4.25}=0.9, P>0.05\right.$, figure $\left.6 \mathrm{~B}\right)$ nor soil vegetation cover $\left(F_{4.25}=1.4, P>0.05\right.$, figure $\left.6 \mathrm{C}\right)$ were 
Table 4. Percentage of individuals of herbs in relation to the total number of individuals per species (Total) occurring at the following distances from the forest edge: $0 \mathrm{~m}, 25 \mathrm{~m}, 50 \mathrm{~m}, 100 \mathrm{~m}$ and $250 \mathrm{~m}$. Light requirements are: $\mathrm{L}=$ light demanding; $\mathrm{S}=$ shade tolerant and $\mathrm{I}=$ indifferent.

\begin{tabular}{|c|c|c|c|c|c|c|c|c|c|}
\hline \multirow[t]{2}{*}{ Species } & \multirow[b]{2}{*}{ Light requirement } & \multicolumn{7}{|c|}{ Individuals for each distance (\%) } & \multirow[b]{2}{*}{ Total } \\
\hline & & $-50 m$ & $-5 \mathrm{~m}$ & $0 \mathrm{~m}$ & $25 \mathrm{~m}$ & $50 \mathrm{~m}$ & $100 \mathrm{~m}$ & $250 \mathrm{~m}$ & \\
\hline Glechon sp. & $\mathrm{L}$ & 100 & & & & & & & 2 \\
\hline Tibouchina cf. gracilis & $\mathrm{L}$ & 100 & & & & & & & 3 \\
\hline Vernonia cf. flexuosa & $\mathrm{L}$ & 100 & & & & & & & 1 \\
\hline Asclepias curassavica & $\mathrm{L}$ & & 100 & & & & & & 1 \\
\hline Eryngium horridum & $\mathrm{L}$ & & 100 & & & & & & 53 \\
\hline Eupatorium sp.2 & $\mathrm{L}$ & & 100 & & & & & & 1 \\
\hline Gomphrena sp. & $\mathrm{L}$ & & 100 & & & & & & 5 \\
\hline Herb 1 & & & 100 & & & & & & 11 \\
\hline Achyrocline satureioides & $\mathrm{L}$ & & & 100 & & & & & 1 \\
\hline Elephantopus mollis & I & & & 100 & & & & & 4 \\
\hline Solanum americanum & $\mathrm{L}$ & & & 100 & & & & & 3 \\
\hline Oxalis sp.2 & $\mathrm{L}$ & & & 100 & & & & & 4 \\
\hline Pterocaulon sp. & $\mathrm{L}$ & & & 100 & & & & & 1 \\
\hline Apiaceae 1 & & & & 100 & & & & & 8 \\
\hline Herb 2 & & & & 100 & & & & & 4 \\
\hline Herb 4 & & & & 100 & & & & & 1 \\
\hline Polypodium sp. & $\mathrm{S}$ & & & & & 100 & & & 1 \\
\hline Herb 5 & & & & & & 100 & & & 1 \\
\hline Thelipteris sp. & I & & & & & & 100 & & 7 \\
\hline Orchidaceae 1 & & & & & & & & 100 & 2 \\
\hline Baccharis sp.1 & $\mathrm{L}$ & 75 & 25 & & & & & & 4 \\
\hline Desmanthus virgatus & $\mathrm{L}$ & 75 & 25 & & & & & & 4 \\
\hline Solidago chilensis & $\mathrm{L}$ & 14 & 86 & & & & & & 7 \\
\hline Eupatorium sp.1 & $\mathrm{L}$ & 33 & 67 & & & & & & 3 \\
\hline Triodanis biflora & $\mathrm{L}$ & 50 & & 50 & & & & & 2 \\
\hline Oxalis sp. 1 & $\mathrm{~L}$ & & 25 & 75 & & & & & 4 \\
\hline Pteridium aquilinum & $\mathrm{L}$ & & 67 & & & & 33 & & 3 \\
\hline Chaptalia nutans & $\mathrm{L}$ & & & 80 & 9 & 6 & 6 & & 54 \\
\hline Hydrocotyle sp. & $\mathrm{S}$ & & & 50 & & & 38 & 13 & 8 \\
\hline Herb 3 & & & & 33 & & 33 & & 33 & 3 \\
\hline Dichondra sp. & $\mathrm{L}$ & & & 8 & & 92 & & & 13 \\
\hline Asplenium sp. & $\mathrm{S}$ & & & & & 25 & 50 & 25 & 4 \\
\hline
\end{tabular}

significantly different among the different distances from the forest edge.

\section{Discussion}

We registered a clear pattern of changes in the plant community due to edge effects that occurred in the first $50 \mathrm{~m}$ from the edge into the forest. Such changes consist of a decrease in understory vegetation cover and a decrease in abundance and richness of woody plants, seedlings and herbs from 25 to $50 \mathrm{~m}$ into the forest. Besides, there was a significant increase of these former parameters at the interface between field and forest (distance $0 \mathrm{~m}$ ). We also found continuous changes in floristic composition along the edge. The proportion of individuals and species found for each life form was similar along the forest gradient studied, however, there was an increase in light-demanding individuals at the edge for all studied life forms. The extension of such alterations in plant communities due to edge effects is comparable to other works done in Brazil and other contries, in which penetration of edge effects varied from 15 to $60 \mathrm{~m}$ into the forest (Williams-Linera 1990a, 1990b, Malcolm 1994, Young \& Mitchell 1994, Baldi 1999, Gehlhausen et al. 2000, Harper \& Macdonald 2002, Honnay et al. 2002). 
Several factors may have influenced the alterations found in the studied forest edge. Distinct abiotic conditions between forest and edge (Kapos 1989, Matlack 1993) commonly cause changes in species composition (Williams-Linera 1990a, Gehlhausen et al. 2000, Oosterhoorn \& Kappelle 2000, Honnay et al. 2002), vegetation structure (Williams-Linera 1990a, Malcolm 1994, Young \& Mitchell 1994, Cadenasso \& Pickett 2001) and tree mortality rate (Laurance et al. 1998, Mesquita et al. 1999, Laurance et al. 2000). In this study grazing and cattle trampling may have caused differential mortality of herbs and woody seedling as observed by Mauhs \& Backes (2002) in a similar study
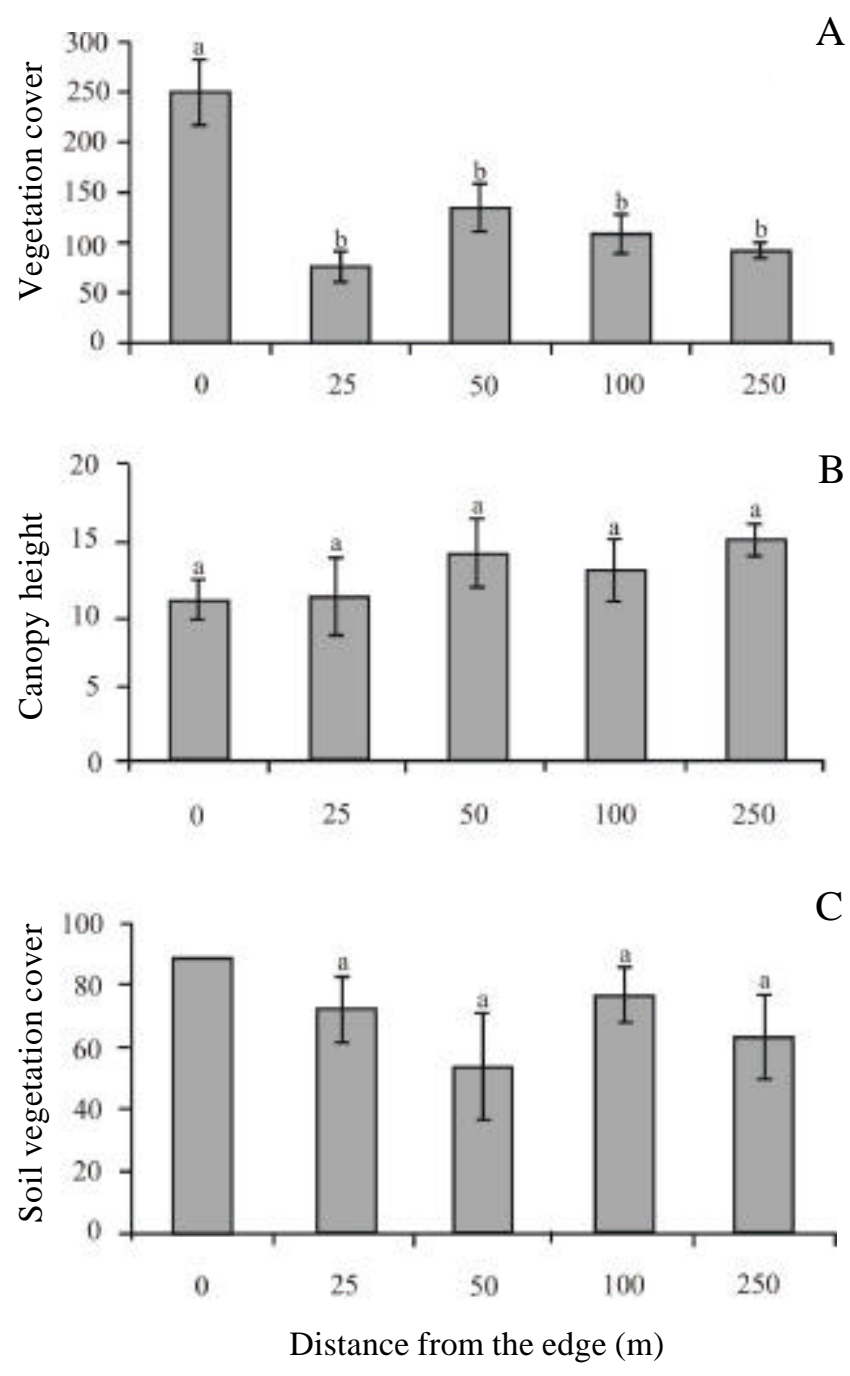

Figure 6. Mean \pm 1 standard error of vegetation cover of understorey plants, (A), canopy height (B) and soil vegetation cover (C) at different distances from a forest edge. Distinct letters indicate significant differences among distances. The study was performed at the National Forest of São Francisco de Paula, Rio Grande do Sul State, South Brazil. area. Additionally, the occasional penetrations of fire may cause significant changes in vegetation structure and composition at the edge affected area that in this study penetratres, at least, up to $50 \mathrm{~m}$ inside the forest (Cochrane \& Laurance 2002). Another factor of great importance that we have observed was the action of strong sporadic winds that caused great damage to vegetation and high mortality of canopy trees at the edge.

Such alterations on vegetation structure may change light intensity nearby a forest edge (Williams-Linera 1990b, Malcolm 1994). Benitez-Malvido (1998) recorded lower seedling abundance at the edge of tropical forest fragments. We found, however, an accentuated increase of seedlings, as found by Sizer \& Tanner (1999), as well as a peak in richness and abundance of woody plants and herbs at the edge $(0 \mathrm{~m})$. This pattern was mainly due to the proliferation of $S$. reitzii, and C. nutans, typical light demanding species. Therefore, the colonization of this species at the edge was probably improved by high light intensity (Kapos 1989, Matlack 1993, Baldi 1999). However, shade-tolerant species that were abundant in the survey such as $R$. parquioides and $S$. oppositifolia, did not occur at the edge. Continuous alterations in the plant community composition along forest edges were also found by Gehlhausen et al. (2000).

Only six seedlings of woody species established in the field, suggesting that forest invasion into the field occurs at slow rates, considering that the studied pasture has been abandoned for five years. We believe that there are three main causes for this pattern. First, soil conditions in this pasture may have been jeopardized by the use of fire. Second, we found a high density of E. horridum in the pasture, and this species is known to be very abundant, and outcompete previously existing species in situations where fields are managed with fire (Boldrini 1997). Third, other works performed at the study area have found high seed predation rates of woody plant species colonizing this abandoned pasture, indicating that post dispersal hazards may limit tree establishment (Baldissera \& Ganade 2005).

The invasion of herbs from the field into the forest was extremely reduced. From the 15 species registered in the field only two occurred at the forest edge. Therefore, the increase in abundance of herbs at the edge may be a consequence of the migration of lightdemanding species coming from the forest interior. These results suggest that the invasion of species from the field towards the forest is relatively slow compared to other studies (Brothers \& Spingarn 1992, Cadenasso 
\& Pickett 2001). This pattern may be due to the high density of vegetation cover at the forest edges that could function as a physical barrier, limiting the arrival of wind dispersed seeds into the forest (Williams-Linera, 1990a, Malcolm 1994, Dihdam \& Lawton 1999, Cadenasso \& Picket 2001, Honnay et al. 2002). Additionally, the edge became a place improper for the invasion of light demanding herbs due to the proliferation of branches and the establishment of a dense shrub and tree community (Brothers \& Spingarn 1992).

All these changes in vegetation structure and composition along this edge of Araucaria forest and field may have great consequences over the fauna diversity (Murcia 1995). These results bring important information for management and conservation plans of fragmented areas of Araucaria forest. An extension of $50 \mathrm{~m}$ around the forest fragment should be considered altered by edge effects. Therefore, fragments with a high edge/interior ratio should not be characterized as intact native forest, and management plans for conserving forest remnants should give preference to areas with low edge/interior ratio (Lovejoy et al. 1986).

Acknowledgements - We are grateful to Ibama for providing the study site and field structure and Unisinos for financial support. We thank Cristiane Leis, Fernanda Pereira and Ronei Baldissera for their help in the field work, Lessandra Zanini for her contribution with the graphs layout and Carlos Roberto Fonseca for comments on the early versions of the manuscript. Simone Benedet Fontoura received a scholarship from Unisinos.

\section{References}

AIZEN, M.A. \& FEINSINGER, P. 1994. Forest fragmentation, pollination, and plant reproduction in a Chaco Dry forest, Argentina. Ecology 75:330-351.

BACKES, A. 1999. Condicionamento climático e distribuição geográfica de Araucaria angustifolia (Bertol.) O. Kuntze no Brasil II. Pesquisas - Botânica 49:31-51.

BALDI, A. 1999. Microclimate and vegetation edge effects in a reedbed in Hungary. Biodiversity and Conservation 8:1697-1706.

BALDISSERA, R. \& GANADE, G. 2005. Predação de sementes ao longo de uma borda de floresta ombrófila mista e pastagem. Acta Botanica Brasilica 19:161-165.

BEHLING, H., PILLAR, V. P., ORLÓCI , L. \& BAUERMANN, S.G. 2004. Late quaternary Araucaria forest, grassland (Campos), fire and climate dynamics, studied by highresolution pollen, charcoal and multivariate analysis of the Cambará do Sul core in southern Brazil. Palaeo 203: 277-297.
BENITEZ-MALVIDO, J. 1998. Impact of forest fragmentation on seedling abundance in a tropical rain forest. Conservation Biology 12:380-389.

BOLDRINI, I.I. 1997. Campos do Rio Grande do Sul: caracterização fisionômica e problemática ocupacional. Boletim do Instituto de Biociências da UFRGS 56:1-39.

BROTHERS, T. \& SPINGARN, A. 1992. Forest fragmentation and alien plant invasion of Central Iiana old-growth forests. Conservation Biology 6:91-100.

CADENASSO, M.L. \& PICKETT, S.T.A. 2001. Effect of edge structure on the flux of species into forest interiors. Conservation Biology 15:91-97.

CAMARGO, J.L.C. \& KAPOS, V. 1995. Complex edge effects on soil moisture and microclimate in Central Amazonian forest. Journal of Tropical Ecology 11:205-221.

COCHRANE, M.A. \& LAURANCE, W.F. 2002. Fire as a largescale edge effect in Amazonian forests. Journal of Tropical Ecology 18:311-325.

DAVIES-COLLEY, R.J., PAYNE, G.W. \& VAN ELSWIJK, M. 2000. Microclimate gradients across a forest edge. New Zealand Journal of Ecology 24:111-121.

DIDHAM, R.K. \& LAWTON, J.H. 1999. Edge structure determines the magnitude of changes in microclimate and vegetation structure in tropical forest fragments. Biotropica 31:17-30.

GALETTI, M., ALVES-COSTA, C.P. \& CAZETTA, E. 2003. Effects of forest fragmentation, anthropogenic edges and fruit color on the consumption of ornithocoric fruits. Biological Conservation 111:269-273.

GASCON, C., LOVEJOY, T.E., BIERREGAARD, R.O., MALCOLM, J.R., STOUFFER, P.C., VASCONCELOS, H.L., LAURANCE, W.F., ZIMMERMAN, B., TOCHER, M. \& BORGES, S. 1999. Matrix habitat and species richness in Tropical forest remnants. Biological Conservation 91:223-229.

GEHLHAUSEN, S.M., SCHWARTZ, M.W.\& AUGSPURGER, C.K. 2000. Vegetation and microclimatic edge effects in two mixed-mesophytic forests fragments. Plant Ecology 147:21-35.

HARPER, K.A. \& MACDONALD, S.E. 2002. Structure and composition of edges next to regenerating clear-cuts in mixed-wood boreal forest. Journal of Vegetation Science 13:535-546.

HONNAY, O., VERHEYEN, K. \& HERMY, M. 2002. Permeability of ancient forest edges for weedy plant species invasion. Forest Ecology and Management 161:109-122.

KAPOS, V. 1989. Effects of isolation on the water status of forest patches in the Brazilian Amazon. Journal of Tropical Ecology 5:173-185.

KAPOS, V., WANDELI, E., CAMARGO, J.L. \& GANADE, G. 1997. Edge-related changes in environment and plant responses due to forest fragmentation in central Amazonia. In Tropical forest remnants (W.F. Laurance \& R.O. Birregaard, eds.). Chicago University Press, New York, p.33-44. 
KOLLMANN, J. \& BUSCHOR, M. 2003. Edge effects on seed predation by rodents in deciduous forests of northern Switzerland. Plant Ecology 164:249-261.

KÖPPEN, W. 1936. Das geographische System der Klimate. Handbuch der Klimatologie, v.1, Part C (W. Köppen \& R. Geiger, eds.). Gerbrüder Bornträger, Berlin, p. C1-C44.

LAURANCE, W.F. \& BIERREGAARD, R.O. (eds.). 1996. Tropical Forest Remnants: Ecology, Management, and Conservation of Fragmented Communities. Chicago University press, New York.

LAURANCE, W.F., FERREIRA, L.V., RANKIN-DE MERONA, J.M. \& LAURANCE, S.G. 1998. Rain forest fragmentation and the dynamics of Amazonian tree communities. Ecology 79:2032-2040.

LAURANCE, W.F., DELAMÔNICA, P., LAURANCE, S., VASCONCELOS, H.L. \& LOVEJOY, T.E. 2000. Rainforest fragmentation kills big trees. Nature 404:836.

LOVEJOY, T.E., BIERREGAARD, R.O., RYLANDS, A.B., MALCOLM, J.R., QUINTELA, C.E., HARPER, L.H., BROWN, K.S., POWELL, A.H., POWELL, G.V.N., SCHUBART, H.O.R. \& HAYS, M.B. 1986. Edge and other effects of isolation on Amazon forests fragments. In Conservation Biology (M.E. Soulé, ed.). Sinauer, Massachusetts, p.257-285.

MALCOLM, J.R. 1994. Edge effects in Central Amazonian forest fragments. Ecology 75:2438-2445.

MATLACK, G.R. 1993. Microenvironment variation within and among forest edge sites in the eastern United States. Biological Conservation 66:185-194.

MAUHS, J. \& BACKES, A. 2002. Estrutura fitossociológica e regeneração natural de um fragmento de Floresta Ombrófila Mista exposto a perturbações antrópicas. Pesquisas-Botânica 52:89-109.

MEINERS, S.J., PICKETT, S.T.A. \& HANDEL, S.N. 2002. Probability of tree seedling establishment changes across a forest-old field edge gradient. American Journal of Botany 89:466-471.

MESQUITA, R.C.G., DELAMÔNICA, P. \& LAURANCE, W.F. 1999. Effect of surrounding vegetation on edge-related tree mortality in Amazonian Forest fragments. Biological Conservation 91:129-134.
MURCIA, C. 1995. Edge effects in fragmented forests: implications for conservation. Tree 10:58-62.

OOSTERHOORN, M. \& KAPPELLE, M. 2000. Vegetation structure and composition along an interior-edgeexterior gradient in a Costa Rica montane cloud forest. Forest Ecology and Management 126:291-307.

RAMBO, B. 1956. A fisionomia do Rio Grande do Sul. Editora Unisinos, São Leopoldo.

REDDING, T.E., HOPE, G.D., FORTIN, M.J., SCHMIDT, M.G. \& BAILEY, W.G. 2003. Spatial patterns of soil temperature and moisture across subalpine forest-clearcut edges in the southern interior of British Columbia. Canadian Journal of Soil Science 83:121-130.

REITZ, R. 1965-1989. Flora Ilustrada Catarinense. HBR, Itajaí.

RESTREPO, C. \& VARGAS, A. 1999. Seeds and seedlings of two neotropical montane understory shrubs respond differently to anthropogenic edges and treefall gaps. Oecologia 119:419-426.

SECRETARIA ESTADUAL DO MEIO AMBIENTE. 2001. Inventário Florestal Contínuo do Rio Grande do Sul. Impresso pelo Governo do Estado do Rio Grande do Sul.

SIZER, N. \& TANNER, E.V.J. 1999. Responses of woody plant seedlings to edge formation in a lowland tropical rainforest, Amazonia. Biological Conservation 91:135-142.

TEIXEIRA, M.B., COURA NETO, A.B., PASTORE, U. \& RANGEL FILHO, A.L.R. 1986. Vegetação: levantamento de recursos naturais, v. 33. IBGE, Rio de Janeiro, p.541-620.

WILLIAMS-LINERA, G. 1990a. Vegetation structure and environmental conditions in forest edges in Panama. Journal of Ecology 78:356-373.

WILLIAMS-LINERA, G. 1990b. Origin and early development of edge vegetation in Panama. Biotropica 22:235-241.

YOUNG, A. \& MITCHELL, N. 1994. Microclimate and vegetation edge effects in a fragmented PodocarpBroadleaf forest in New Zealand. Biological Conservation 67:63-72.

ZAR, J.H. 1984. Biostatistical analysis. Prentice-Hall, London. 